\title{
Heavy metals distribution in the coral reef ecosystems of the Northern Red Sea
}

\author{
Abdel-hamid A. M. Ali • Mohamed A. Hamed • \\ Hoda Abd El-Azim
}

Received: 2 June 2009 / Revised: 5 April 2010 / Accepted: 15 April 2010 / Published online: 30 May 2010

(C) Springer-Verlag and AWI 2010

\begin{abstract}
Concentrations of seven heavy metals $(\mathrm{Cu}, \mathrm{Zn}$, $\mathrm{Pb}, \mathrm{Cd}, \mathrm{Ni}, \mathrm{Co}$ and $\mathrm{Fe}$ ) were measured in the seawater, sediments, common scleractinian reef-building corals and soft corals (Octocorallia : Alcyonacea) at seven reef sites in the Northern Red Sea: I (Hurghada), II (Ras Za'farana), III (El-Ain Al-Sukhna), IV (El-Tur), V (Sha'b Rashdan), VI (Sharm El-Sheikh) and VII (Dahab). Levels of heavy metals were considerably elevated in seawater, sediments and corals collected from reef sites exposed to increased environmental contamination, as a result of diversified natural and anthropogenic inputs. Soft corals of genera Lithophyton, Sarcophyton and Sinularia showed higher concentrations of $\mathrm{Zn}, \mathrm{Pb}, \mathrm{Cd}$ and Ni than hard coral genera Acropora and Stylophora. Soft coral Sarcophyton trocheliophorum collected from El Ain Al-Suhkna (Gulf of Suez) had greater concentration of $\mathrm{Cu}$, followed by hard corals Acropora pharaonis and Acropora hemprichi. The elevated levels of $\mathrm{Zn}, \mathrm{Cd}$ and $\mathrm{Ni}$ were reported in the dry tissue of soft coral Sinularia spp. On the other hand, the soft coral Lithophyton arboreum displayed the highest concentration of $\mathrm{Pb}$ at Sha'b Rashdan (Gulf of Suez) and elevated concentration of $\mathrm{Zn}$ at Sharm El-Sheikh. Sediments showed significantly higher concentration of $\mathrm{Fe}$ than corals. The higher levels of Fe in hard corals than soft corals reflected the incorporation of $\mathrm{Fe}$ into the aragonite and the chelation with the organic matrix of the skeleton. The greater abundance of soft corals in metal-contaminated reef sites and the elevated levels of metals in their tissue suggesting that the soft corals could develop a tolerance mechanism
\end{abstract}

Communicated by H.-D. Franke.

A. A. M. Ali · M. A. Hamed ( $ه) \cdot H$. Abd El-Azim

National Institute of Oceanography and Fisheries,

Ataqa, Suez, Egypt

e-mail: drhamed64@yahoo.com to relatively high concentrations of metals. Although the effects of heavy metals on reef corals were not isolated from the possible effects of other stresses, the percentage cover of dead corals were significantly higher as the concentrations of heavy metals increased.

Keywords Coral reefs $\cdot$ Heavy metals $\cdot$ Soft corals . Hard corals $\cdot$ Sediments

\section{Introduction}

Coral reefs are common feature of many shallow coastal environments in tropical regions and are at increasing risk from pollution pressures. The negative effects of chemical contaminants on coral reef ecosystems are of increasing concern as human population and activities expand adjacent to coral reef communities. Three classes of pollutants have received attention: heavy metals, petroleum and synthetic organics such as herbicides and pesticides. The main stress responses of coral reefs to the elevated levels of heavy metals reported in the literature can be summarized in the following: physiological stress (Howard and Brown 1984; Harland and Brown 1989); inhibition of coral fertilization and reduced reproductive success (Heyward 1988; Reichelt-Brushett and Harrison 1999, 2005; ReicheltBrushett and Michalek-Wagner 2005); decreased settlement and survival of coral larvae (Esquivel 1983; Goh 1991; Reichelt-Brushett and Harrison 2000); changes in the population and growth of zooxanthellae (endosymbiotic algae) (Kayser 1976); changes in the rate of photosynthesis resulted in a decrease in coral calcification and growth rates during the juvenile polyp stage (Harland and Brown 1989; Falkowski et al. 1993; Ferrier-Pages et al. 2001); increased coral bleaching (Sabdono 2009); enhanced coral mortality 
and lowered live corals (Abdel-Salam 1989; Mitchelmore et al. 2007; Sabdono 2009); and outright mortality in associated invertebrates and fishes (Peters et al. 1997). The biggest problems with heavy metals are that they are persistent and they bioaccumulate. So, in addition to posing a threat to the health of corals around the world, toxic metals also pose a long-term public health risk, especially for those human populations that rely on fish and invertebrates for protein. Although there are some natural sources of these metals, the majority of heavy metals found in nearshore waters are anthropogenic. Some of these anthropogenic heavy metals come from sources at the sea such as the drilling fluid used in offshore oil production and accidental oil spill from petroleum tankers, however, the majority of sources are land-based.

Trace metals can be incorporated into corals by a variety of mechanisms: substitution of dissolved metals species into crystal lattice (e.g. substitution for Ca), trapping of particulate (detritus) matter within skeletal cavities, uptake of organic matter from coral tissue, and coral feeding (Brown 1987; Hanna and Muir 1990; Ferrier-Pagès et al. 2005). The most likely mechanism for incorporation of metals in corals is a combination of uptake of seawater-soluble metals and incorporation via polyp feeding (Fallon et al. 2002; Ramos et al. 2004). Incorporation by coral feeding can be accomplished in two ways. One is by tentacular capture of zooplankton where the zooplankton is exposed and accumulates metals ( $\mathrm{Cd}, \mathrm{Mn}, \mathrm{Pb}, \mathrm{Zn}$ and others). A second is by mucus nets that trap zooplankton and fine particulate material, which is periodically ingested by the corals. Either of the proposed mechanisms may cause corals exposed to elevated soluble and particulate metals, which have increased skeletal concentrations (Fallon et al. 2002; Corrège 2006). Regardless of the incorporation mechanisms, corals have been shown to be good tracers of pollutants in the marine environment (e.g. Dodge and Gilbert 1984; Scott 1990; Guzman and Jimenez 1992; Bastidas and Garcia 1999; Fallon et al. 2002; Ramos et al. 2004; Al-Rousan et al. 2007; Anu et al. 2007; Jayaraju et al. 2009). This study was designed to assess the heavy metals levels in coral reef ecosystems in the Northern Red Sea and provide appropriate information to coral reef managers and conservators. So with this information, an effective management strategy can be implemented to protect the coral reef ecosystems from the sources these persistent pollutants.

\section{Materials and methods}

\section{Study sites}

The survey was conducted during the year 2008 (from January to November) in seven locations (Fig. 1) along the
Red Sea coast of Egypt: I (Hurghada), II (Ras Za'farana), III (El-Ain Al-Sukhna), IV (El-Tur), V (Sha'b Rashdan), VI (Sharm El-Sheikh) and VII (Dahab). Sampling locations have been selected to cover the most endangered coral reefs and considering the significant contamination sources in the area: (1) terrestrial runoff from large coastal cities, (2) harbors, (3) construction activities for tourism expansion, (5) recreational and fishing activities, (6) oil spillage associated with petroleum operations and shipping, and so forth.

Site I (Hurghada) is located at $27^{\circ} 17^{\prime} \mathrm{N}$ and $33^{\circ} 46^{\prime} \mathrm{E}$, nearby Hurghada city. It lies also adjacent to Hurghada Youth House, National Youth Camp, Faculty of education, and number of tourist hotels and recreational resorts.

Site II (Ras Za'farana) is located at $29^{\circ} 07^{\prime} \mathrm{N}$ and $32^{\circ} 39^{\prime} \mathrm{E}$, adjacent to Suez-Hurghada high way, $120 \mathrm{~km}$ south of Suez city and $60 \mathrm{~km}$ south of El-Ain Al-Sukhna. It is situated in between two tourist villages, and the area is subjected to massive construction of tourist villages and recreational resorts in the last 5 years. The reef is threatened also by the accidental oil spill resulted from traveling tankers and damage of shoreline oil pipeline extended in the area.

Site III (El-Ain Al-Sukhna) is situated at about $60 \mathrm{~km}$ south of Suez city $\left(29^{\circ} 33^{\prime} \mathrm{N}\right.$ and $32^{\circ} 21^{\prime} \mathrm{E}$ ), neighbor to Suez-Hurghada high way. The reef lies also immediately underneath Ataqa Mountain and in the face of offshore transit area for ships (Cargo and tankers) that waiting to cross the Suez Canal. It is located close SUMED pipeline platform terminals, where shipping and unloading operations for crude oil are the routine activity. New El-Ain Al-Sukhna commercial port, Gulf of Suez Power Plant and harbor for recreational boats are existed also in the area in the vicinity of Site III.

Site IV (El-Tur) is located in the east coast of Gulf of Suez at $28^{\circ} 09^{\prime} \mathrm{N}$ and $33^{\circ} 38^{\prime} \mathrm{E}$, near El-Tur city (capital of South Sinai Governorate). Two harbors are found in El-Tur city, commercial and fishing harbors located also in the vicinity of site IV. There are number of oil production fields in the front of El-Tur area inside the Gulf of Suez.

Site V (Sha'b Rashdan) is considered an offshore reef $\left(28^{\circ} 01^{\prime} \mathrm{N}\right.$ and $\left.33^{\circ} 44^{\prime} \mathrm{E}\right)$ distant from the land-based pollution. However, it is exposed to mechanical damage caused by the illegal fishing practices in the area.

Site VI (Sharm El-Sheikh) is located at $27^{\circ} 50^{\prime} \mathrm{N}$ and $34^{\circ} 18^{\prime} \mathrm{E}$; near Sharm El-Sheikh city the most important Egyptian tourist center and recreational resort on the west coast of Gulf of Aqaba. The region is crowded by hotels and tourist villages, and subjected to intensive construction of new tourist projects. This reef is a popular diving site suffered from high visitor frequency by divers, snorkelers and diving boats. The area comprises also Sharm El-Sheikh port for recreational and diving boats. 
Fig. 1 Location map of the study area. Study sites: I Hurghada, II Ras Za'farana, III El-Ain Al-Sukhna, IV El-Tur, $V$ Sha'b Rashdan, VI Sharm El-Sheikh, VII Dahab

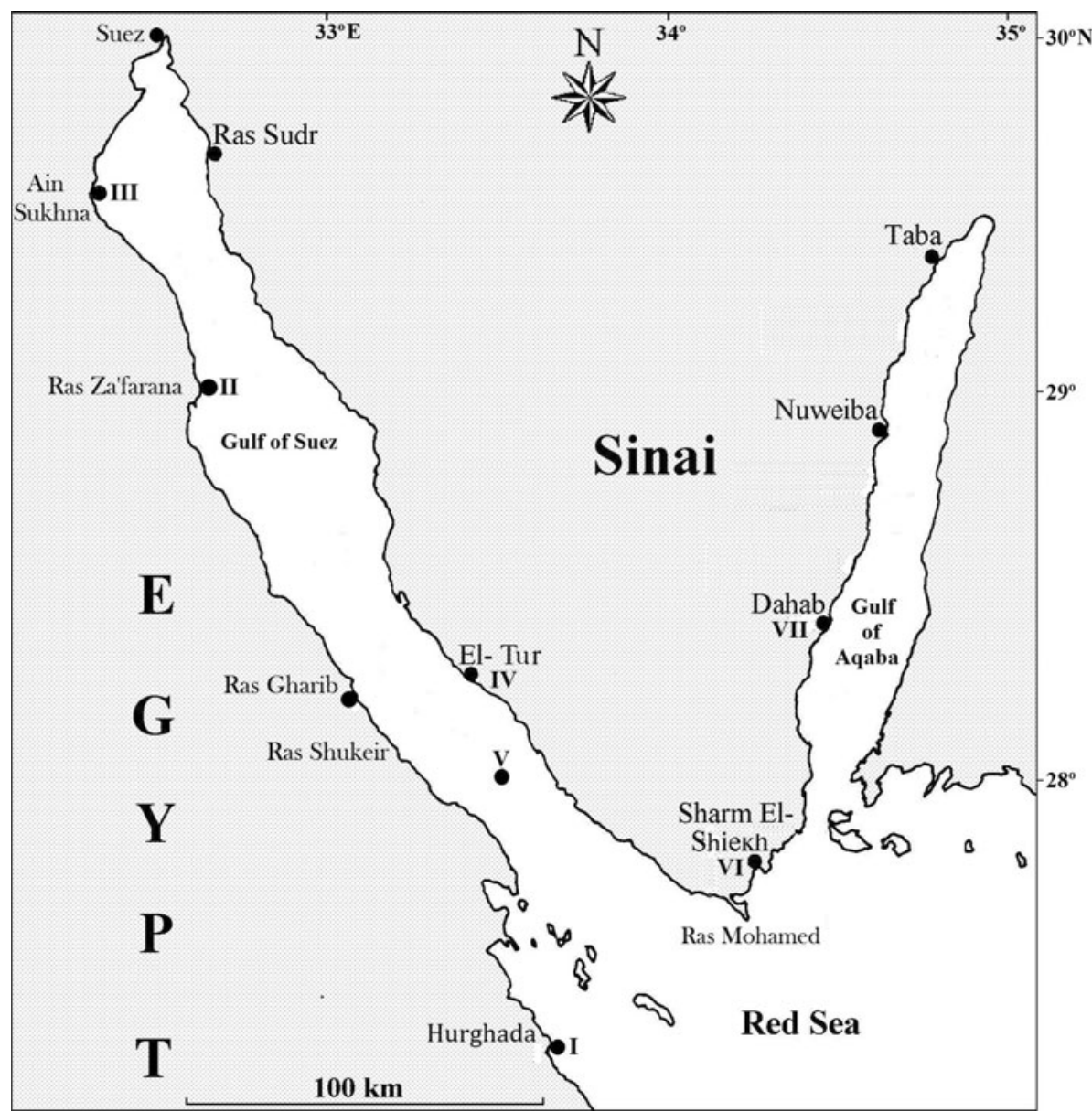

Site VII (Dahab) located immediately on the beach of Dahab city $\left(28^{\circ} 30^{\prime} \mathrm{N}\right.$ and $\left.34^{\circ} 31^{\prime} \mathrm{E}\right)$, close to coffee bars and recreational resorts existed on the beach. Dahab is the second important Egyptian tourist city on the west coast of Gulf of Aqaba. This site is air-exposed area characterized by high wave action and strong currents, which continuously clean the reef from accumulated sediments and pollutants.

Heavy metal analysis

\section{Seawater}

Water samples were collected four times from the surveyed reef sites during 2008 on January (winter season), April (spring season), July (summer season) and November (autumn season). During each season, triplicate samples (1 1 each) were collected from each site in acid-washed polyethylene bottles, using Nisken's bottle. Samples were then transported immediately in icebox to the laboratory where the $\mathrm{pH}$ of samples was adjusted to 3.0 by addition of hydrochloric acid (Brown and Holley 1982).

The metals in seawater were extracted by APDC (ammonium pyrrollidine dithiocarbamate) and MIBK (methyl isobutyl ketone) treatment as described by APHA (1989) and the resulting solutions were analyzed for determination of $\mathrm{Cu}, \mathrm{Zn}, \mathrm{Pb}, \mathrm{Cd}, \mathrm{Ni}$, $\mathrm{Co}$ and $\mathrm{Fe}$ concentrations by Atomic Absorption Spectrophotometry.

Ten milliliters of APDC suspension was added to 11 of sample with continuous shaking for complete chelation. A volume of $50 \mathrm{ml}$ of MIBK was then added and mixed well by a magnetic stirrer for $5 \mathrm{~min}$ for complete extraction. The resulting organic layer was drawn, evaporated until dryness and dissolved in $2 \mathrm{ml}$ of concentrated nitric acid before analysis. Concentrations of soluble heavy metals are expressed as $\mu \mathrm{g}^{-1}$ (or ppb).

\section{Sediments}

Sediments were collected from the seven studied sites on July 2008 using a specially fabricated stainless steel coring device. Approximately 0.5 -inch top layer of reef sediment was carefully removed (skimmed) before sample collection. Subsamples were packed in polythene bags and transported to the laboratory in icebox storage. The sediment samples were then rinsed in distilled water and dried at room temperature until constant weight. The dried sediment 
samples were ground and homogenized in an agate mortar to a fine powder. For the determination of the total trace concentrations, the homogenized dried sediment samples (0.5 $\mathrm{g}$ for each) were digested in Teflon vessels with a mixture of concentrated $\mathrm{HNO}_{3}, \mathrm{HClO}_{4}$ and $\mathrm{HF}$ acids (in the ratio of $3: 2: 1$, respectively) and left overnight before heating (Oregioni and Aston 1984). The mixture was then digested at $120^{\circ} \mathrm{C}$ for $1-2 \mathrm{~h}$. The residue of each sample was dissolved in $12 \mathrm{~N} \mathrm{HCl}$, diluted to $25 \mathrm{ml}$ with deionized distilled water and filtered using Whatman No.1 filter paper. The concentrations of $\mathrm{Cu}, \mathrm{Zn}, \mathrm{Pb}, \mathrm{Cd}, \mathrm{Ni}, \mathrm{Co}$ and $\mathrm{Fe}$ were measured in $\mu \mathrm{gg}^{-1}$ dry weight by atomic absorption spectrophotometry. Three sediment samples were analyzed for each site.

\section{Corals}

Coral specimens were also collected on July 2008. Analysis of heavy metals was performed on four hard coral species, Acropora hemprichi, Acropora pharaonis, Acropora humilis and Stylophora pistillata and three soft coral species, Lithophyton arboreum, Sarcophyton trocheliophorum and Sinularia spp. Some of the intended coral species were lacking at certain sites and hence the concentration of trace metals in these species was not determined at particular sites. Three specimens of each coral species per site were taken and all specimens (skeleton with tissue attached) rinsed in distilled water and dried at room temperature until constant weight. The dried samples were then homogenized and ground to a fine powder in an agate mortar. A concentration $0.5 \mathrm{~g}$ of each homogenized sample was digested in $10 \mathrm{ml}$ of hot $\mathrm{HNO}_{3}$ and diluted to $25 \mathrm{ml}$ with deionized distilled water after complete digestion (Chester et al. 1994). Metal concentrations were determined as $\mu \mathrm{gg}^{-1}$ dry weight using atomic absorption spectrophotometry.

\section{Coral cover}

Data collected using Belt quadrat method (Dodge et al. 1982). In this method, a transect line was employed to act as a guide along which $1-\mathrm{m}^{2}$ quadrat was placed every meter continuously, or at regular intervals (usually $2 \mathrm{~m}$ apart) depending on the transect length and the reef profile. Transects were located parallel to each other and to the reef margin. The quadrat was made of aluminum pipe and divided into 100 squares with nylon line each square therefore represented $1 \%$ of the quadrat. The following attributes were recorded in each quadrat: total number of coral species, living coverage of each species (\%); percentage covers of live hard corals, soft corals and dead corals. These attributes were again calculated at the level of each reef site.
Statistical analysis

Statistical analysis was carried out using the computer STATISTICA software package. Cluster analysis (tree clustering) was performed based on pollution sources to indicate the similarity among the studied locations, as well as among the measured trace metals. Trace metal concentrations in seawater and sediment were correlated with total organic matter, live coral cover and dead coral cover using regression analysis. The coefficient of determination $\left(r^{2}\right)$ was determined to test the strength (magnitude) of each correlation. The correlations were performed for all the studied sites and the $r^{2}$ value are derived from all seven sites. The comparison of trace metal concentrations among coral species was accomplished using one-way analysis of variance (one-way ANOVA) followed by Post hoc tests to determine between which of the species the significant difference occurred. For all analysis, the level of significance was set at $P<0.05$. Data in Tables 1 and 2 are presented as arithmetic means with standard deviation (SD).

Bioconcentration factors (BCFs) was calculated to relate the trace metal residues in coral species to their concentrations in seawaters. Bioconcentration factor is the concentration of a particular chemical in a tissue per concentration of chemical in water.

\section{Results and discussion}

Heavy metals abundances clearly record the dramatic changes in the environmental conditions and provide a basis for identifying anthropogenic influences on coral reefs (e.g. Bastidas and Garcia 1999; Fallon et al. 2002; Corrège 2006; Al-Rousan et al. 2007; Leon 2008; Jayaraju et al. 2009). All metals reported in the present study are mainly the normal constituents of oil, urban and industrial sewage, wastewaters from different sources, terrigenous sediments, atmospheric fallout of industrial pollutants, effluents of power and desalination plants, ports disposals, antifouling and anticorrosive paints that protect the marine vessels and structures, and metal-rich dusts transported from mountains to the sea by the prevailing winds (e.g. Guzman and Jimenez 1992; Machiwa 1992; Al-Abdali et al. 1996; Metwally et al. 1997; Ali 2001; Fallon et al. 2002; Schiff et al. 2004; Mansour et al. 2005).

Based on the sources of pollution, the studied reef sites were divided into two main clusters (Fig. 2). The first cluster include the reefs located nearby the major coastal cities (sites I, IV, VI and VII) and the second cluster include the reefs farther from the coastal cities (II, II and V). The high similarity between site I (Hurghada) and site IV (El-Tur) indicated that the two reef sites exposed to relatively similar sources of pollution since Hurghada and El-Tur are 
Table 1 Mean trace metal concentrations in seawater $\left(\mu \mathrm{g} 1^{-1}, n=12\right.$ per site) and reef sediments ( $\mu \mathrm{g} \mathrm{g}^{-1}$ dry weight, $n=3$ per site $)$ in the sampling locations. Standard deviations are given in parentheses

\begin{tabular}{|c|c|c|c|c|c|c|c|c|}
\hline \multirow[t]{2}{*}{ Metal } & \multirow[t]{2}{*}{ Sample } & \multicolumn{7}{|c|}{ Locations } \\
\hline & & I & II & III & IV & V & VI & VII \\
\hline \multirow[t]{2}{*}{$\mathrm{Cu}$} & W & $3.35(0.56)$ & $3.97(0.59)$ & $5.23(0.98)$ & $3.22(0.85)$ & $2.41(0.64)$ & $2.45(0.55)$ & $2.08(0.54)$ \\
\hline & $\mathrm{S}$ & $7.30(1.36)$ & $8.18(1.09)$ & $11.25(1.29)$ & $3.58(0.81)$ & $1.09(0.27)$ & $6.82(1.11)$ & $2.79(0.42)$ \\
\hline \multirow[t]{2}{*}{$\mathrm{Zn}$} & W & $11.74(1.52)$ & $12.41(1.49)$ & $15.21(1.19)$ & $7.31(0.92)$ & $8.01(0.90)$ & $9.10(1.09)$ & $7.18(0.92)$ \\
\hline & $\mathrm{S}$ & $25.42(3.65)$ & $26.09(2.24)$ & $25.44(2.93)$ & $27.80(3.35)$ & $3.09(0.49)$ & $18.96(1.68)$ & $14.90(0.95)$ \\
\hline \multirow[t]{2}{*}{$\mathrm{Pb}$} & W & $0.68(0.13)$ & $0.62(0.06)$ & $0.80(0.04)$ & $0.59(0.03)$ & $0.43(0.02)$ & $0.61(0.03)$ & $0.37(0.04)$ \\
\hline & $\mathrm{S}$ & $10.55(1.62)$ & $11.09(1.13)$ & $12.64(1.57)$ & $10.04(0.78)$ & $6.68(0.99)$ & $8.61(0.71)$ & $3.67(0.20)$ \\
\hline \multirow[t]{2}{*}{$\mathrm{Cd}$} & W & $0.32(0.01)$ & $0.22(0.01)$ & $0.43(0.01)$ & $0.23(0.01)$ & $0.20(0.01)$ & $0.13(0.00)$ & $0.17(0.02)$ \\
\hline & $\mathrm{S}$ & $3.72(0.60)$ & $3.15(0.36)$ & $4.30(0.91)$ & $3.42(0.59)$ & $2.48(0.28)$ & $3.29(0.34)$ & $1.97(0.27)$ \\
\hline \multirow[t]{2}{*}{$\mathrm{Ni}$} & W & $2.92(0.29)$ & $4.31(0.56)$ & $5.80(0.99)$ & $3.48(0.64)$ & $2.79(0.41)$ & $3.12(0.39)$ & $2.33(0.26)$ \\
\hline & $\mathrm{S}$ & $13.08(0.53)$ & $16.36(1.07)$ & $18.00(1.38)$ & $14.23(1.27)$ & $11.84(0.91)$ & $9.67(1.18)$ & $4.25(0.41)$ \\
\hline \multirow[t]{2}{*}{ Co } & W & $0.45(0.04)$ & $0.40(0.03)$ & $0.52(0.03)$ & $0.34(0.02)$ & $0.21(0.01)$ & $0.30(0.04)$ & $0.25(0.01)$ \\
\hline & $\mathrm{S}$ & $12.17(0.38)$ & $14.02(0.74)$ & $13.29(0.66)$ & $11.54(0.82)$ & $5.16(0.46)$ & $7.95(0.49)$ & $5.21(0.40)$ \\
\hline \multirow[t]{2}{*}{$\mathrm{Fe}$} & W & $13.88(0.94)$ & $23.55(2.43)$ & $28.35(3.04)$ & $13.97(1.01)$ & $10.44(0.81)$ & $12.14(0.98)$ & $9.10(0.62)$ \\
\hline & $\mathrm{S}$ & $1430.30(136.50)$ & $776.82(60.73)$ & $1285.00(89.50)$ & $2150.60(155.94)$ & $321.50(39.46)$ & $2104.70(126.45)$ & $790.90(59.66)$ \\
\hline
\end{tabular}

W: seawater, S: sediment

large coastal cities along the Egyptian Red Sea coast and characterized by high population density and growth. On the other hand, the dendrogram reveals also high similarity between sites II (Ras Za'farana) and III (E-Ain Al-Sukhna). These sites are impacted by oil pollution and massive construction activities.

As shown in Fig. 3, the trace metals in the area of study are grouped in two distinct clusters according to the pollution sources the first cluster comprises $\mathrm{Cu}, \mathrm{Zn}$ and $\mathrm{Ni}$, while the second cluster comprises $\mathrm{Pb}, \mathrm{Cd}, \mathrm{Co}$ and $\mathrm{Fe} . \mathrm{Cu}$ and $\mathrm{Zn}$ showed high similarity since the main pollution sources of these two metals in the area of study are the antifouling and anticorrosive paints, harbors and sewage (Esslemont 2000; Leon and Warnken 2008). The dendrogram displayed also high similarity between $\mathrm{Pb}$ and $\mathrm{Cd}$, where these metals are presumably derived from similar sources of pollution, particularly sewage discharge, wastewater and municipal pipeline (Jayaraju et al. 2009).

\section{Copper}

Copper concentrations in seawater range from $8 \times$ $10^{-4} \mu \mathrm{g} 1^{-1}$ in pristine open oceans up to $29.2 \mu \mathrm{g} \mathrm{l^{-1 }}$ at highly polluted sites (Sadiq 1992). The Australian water quality guidelines stated that copper concentrations in marine waters should not increase than $5 \mu \mathrm{g}^{-1}$ (ANZECC 1992). Antifouling and anticorrosive paints used to protect the ships hulls, recreational vessels and fishing boats (Schiff et al. 2004; Leon and Warnken 2008); domestic and industrial sewage discharge (Jayaraju et al. 2009); wastewater disposal; chronic and accidental oil spill during production, shipping, transfer and processing; effluents from ports; runoff from power and desalination plants; and terrestrial runoff are the major sources of copper in the area of study. Table 1 shows considerable variations in the levels of copper among the investigated sites. Site III (El-Ain Al-Sukhna) showed the highest copper concentration in seawater and sediments, while the lowest concentrations in seawater and sediments were recorded at sites VII (Dahab) and site V (Sha'b Rashdan), respectively. The range of copper concentrations $\left(2.08 \pm 0.54-5.23 \pm 0.98 \mu \mathrm{g} \mathrm{l}^{-1}\right)$ in the investigated sites exceeds the concentration in pristine open oceans (Sadiq 1992). In addition, the copper concentration in seawater measured at site III $\left(5.23 \pm 0.98 \mu \mathrm{g} \mathrm{l}^{-1}\right)$ exceeds the critical threshold of Australian Water quality Guidelines $\left(5 \mu \mathrm{g}^{-1}\right)$. The highest $\mathrm{Cu}$ concentrations in corals were recorded in soft corals Sarcophyton trocheliophorum and hard corals Acropora pharaonis at site III (Table 2). Thus, the elevated $\mathrm{Cu}$ concentrations in corals observed at site III are closely related to those in seawater and sediments in this area. On the contrary, corals at site II (Ras Za'farana) did not reflect the elevated $\mathrm{Cu}$ concentrations in seawater and sediments at this site (Table 1). This may be attributed to the fact that the ability of corals to take and accumulate metals in their tissue is dependent on the physical and chemical characteristics of metals and the environmental factors of seawater in which they live including water currents, dissolved oxygen, $\mathrm{pH}$, salinity and temperature (Waldichuk 1985; Shen et al. 1991). Copper is one of the metals readily removed from solution 
Table 2 Mean trace metal concentrations ( $\mu \mathrm{g} \mathrm{g}^{-1}$ dry weight) in coral species (skeleton plus tissue) collected from the sampling reef sites $(n=3$ per site)

\begin{tabular}{|c|c|c|c|c|c|c|c|c|}
\hline \multirow[t]{2}{*}{ Metal } & \multirow[t]{2}{*}{ Species } & \multicolumn{7}{|c|}{ Locations } \\
\hline & & I & II & III & IV & $\mathrm{V}$ & VI & VII \\
\hline \multirow[t]{7}{*}{$\mathrm{Cu}$} & Acropora hemprichi & $2.10(0.32)$ & - & $9.54(0.89)$ & - & $3.20(0.36)$ & - & - \\
\hline & Acropora pharaonis & $2.19(0.25)$ & $1.15(0.27)$ & $10.44(1.28)$ & $7.19(0.86)$ & $2.63(0.36)$ & $4.05(0.54)$ & $1.56(0.37)$ \\
\hline & Acropora humilis & $2.98(0.34)$ & - & - & $8.66(0.91)$ & $3.25(0.36)$ & $1.28(0.14)$ & $1.35(0.11)$ \\
\hline & Stylophora pistillata & $2.13(0.20)$ & $1.73(0.21)$ & $8.35(1.14)$ & - & $3.00(0.33)$ & $1.77(0.35)$ & $2.50(0.32)$ \\
\hline & Lithophyton arboreum & $3.21(0.58)$ & $2.92(0.49)$ & $3.63(0.16)$ & - & $5.00(0.39)$ & $3.38(0.43)$ & $2.60(0.27)$ \\
\hline & $\begin{array}{l}\text { Sarcophyton } \\
\quad \text { trocheliophorum }\end{array}$ & $4.95(0.60)$ & - & $13.66(1.55)$ & $4.65(0.95)$ & $4.25(0.65)$ & - & - \\
\hline & Sinularia spp. & $5.50(1.18)$ & - & $4.13(0.19)$ & $9.39(0.77)$ & $4.88(0.53)$ & $2.83(0.26)$ & $3.33(0.28)$ \\
\hline \multirow[t]{7}{*}{$\mathrm{Zn}$} & Acropora hemprichi & $58.35(2.87)$ & - & $36.63(2.60)$ & - & $26.09(1.88)$ & - & - \\
\hline & Acropora pharaonis & $21.22(2.43)$ & $6.73(0.62)$ & $45.08(2.80)$ & $17.46(1.46)$ & $19.99(2.04)$ & $32.65(2.93)$ & $0.54(0.09)$ \\
\hline & Acropora humilis & $25.94(2.43)$ & - & - & $56.72(2.46)$ & $8.12(1.49)$ & $20.62(2.48)$ & $3.18(0.41)$ \\
\hline & Stylophora pistillata & $15.68(1.58)$ & $9.28(0.92)$ & $41.44(2.48)$ & - & $20.48(1.86)$ & $5.66(0.92)$ & $7.62(0.95)$ \\
\hline & Lithophyton arboreum & $58.19(4.33)$ & $82.56(7.29)$ & $81.19(3.87)$ & - & $82.39(3.98)$ & $123.60(12.43)$ & $61.13(3.91)$ \\
\hline & $\begin{array}{l}\text { Sarcophyton } \\
\quad \text { trocheliophorum }\end{array}$ & $29.85(2.46)$ & - & $37.06(2.63)$ & $74.50(5.51)$ & $59.06(2.35)$ & - & - \\
\hline & Sinularia spp. & $31.28(3.66)$ & - & $141.30(16.87)$ & $50.30(4.46)$ & $31.36(2.33)$ & $51.61(3.78)$ & $38.67(3.53)$ \\
\hline \multirow[t]{7}{*}{$\mathrm{Pb}$} & Acropora hemprichi & $9.16(0.85)$ & - & $7.12(0.86)$ & - & $31.42(3.19)$ & - & - \\
\hline & Acropora pharaonis & $16.36(1.47)$ & $29.96(2.96)$ & $8.59(0.97)$ & $27.27(2.72)$ & $32.72(2.92)$ & $29.45(3.18)$ & $24.54(2.36)$ \\
\hline & Acropora humilis & $14.18(0.52)$ & - & - & $26.18(1.78)$ & $25.45(2.38)$ & $25.20(3.27)$ & $21.27(2.15)$ \\
\hline & Stylophora pistillata & $12.36(1.27)$ & $26.47(1.72)$ & $6.89(0.35)$ & - & $29.09(2.32)$ & $24.72(2.52)$ & $30.54(2.77)$ \\
\hline & Lithophyton arboreum & $36.00(2.53)$ & $14.54(1.29)$ & $28.40(3.49)$ & - & $36.36(2.97)$ & $34.36(2.93)$ & $14.18(2.39)$ \\
\hline & $\begin{array}{l}\text { Sarcophyton } \\
\quad \text { trocheliophorum }\end{array}$ & $18.54(1.69)$ & - & $11.63(1.09)$ & $20.29(1.95)$ & $24.72(2.06)$ & - & - \\
\hline & Sinularia spp. & $36.00(2.59)$ & - & $16.36(1.14)$ & $32.07(2.67)$ & $36.01(2.01)$ & $27.81(1.63)$ & $26.18(2.10)$ \\
\hline \multirow[t]{7}{*}{$\mathrm{Cd}$} & Acropora hemprichi & $0.60(0.03)$ & - & $1.34(0.20)$ & - & $3.76(0.52)$ & - & - \\
\hline & Acropora pharaonis & $1.31(0.15)$ & $3.54(0.49)$ & $2.05(0.28)$ & $2.07(0.31)$ & $3.04(0.20)$ & $3.10(0.30)$ & $1.82(0.31)$ \\
\hline & Acropora humilis & $1.62(0.23)$ & - & - & $2.11(0.25)$ & $3.26(0.66)$ & $2.79(0.35)$ & $1.84(0.19)$ \\
\hline & Stylophora pistillata & $0.54(0.03)$ & $3.06(0.44)$ & $1.26(0.09)$ & - & $3.33(0.61)$ & $2.88(0.23)$ & $2.78(0.24)$ \\
\hline & Lithophyton arboreum & $4.56(0.76)$ & $1.40(0.17)$ & $2.47(0.32)$ & - & $2.92(0.31)$ & $4.11(0.48)$ & $3.10(0.36)$ \\
\hline & $\begin{array}{l}\text { Sarcophyton } \\
\quad \text { trocheliophorum }\end{array}$ & $2.41(0.24)$ & - & $0.89(0.12)$ & $1.58(0.21)$ & $1.69(0.19)$ & - & - \\
\hline & Sinularia spp. & $3.82(0.43)$ & - & $9.59(0.69)$ & $3.52(0.33)$ & $4.11(0.40)$ & $1.98(0.24)$ & $2.51(0.20)$ \\
\hline \multirow[t]{7}{*}{$\mathrm{Ni}$} & Acropora hemprichi & $1.35(0.17)$ & - & $8.22(0.75)$ & - & $14.53(1.56)$ & - & - \\
\hline & Acropora pharaonis & $5.74(0.74)$ & $12.11(0.79)$ & $9.01(0.15)$ & $7.11(0.72)$ & $11.74(1.10)$ & $11.66(1.15)$ & $9.84(0.98)$ \\
\hline & Acropora humilis & $6.25(0.50)$ & - & - & $10.02(0.66)$ & $9.83(0.64)$ & $8.10(0.65)$ & $10.970 .80)$ \\
\hline & Stylophora pistillata & $1.61(0.17)$ & $13.22(1.13)$ & $7.88(0.62)$ & - & $11.47(0.72)$ & $13.20(0.85)$ & $13.65(0.64)$ \\
\hline & Lithophyton arboreum & $18.20(1.29)$ & $7.11(0.58)$ & $11.23(0.79)$ & - & $11.65(0.66)$ & $12.15(0.83)$ & $6.84(0.34)$ \\
\hline & $\begin{array}{l}\text { Sarcophyton } \\
\quad \text { trocheliophorum }\end{array}$ & $8.56(0.70)$ & - & $4.20(0.31)$ & $3.81(0.24)$ & $3.15(0.30)$ & - & - \\
\hline & Sinularia spp. & $14.20(1.04)$ & - & $186.00(8.54)$ & $13.13(0.52)$ & $15.83(1.00)$ & $9.34(0.65)$ & $12.20(0.91)$ \\
\hline \multirow[t]{7}{*}{ Co } & Acropora hemprichi & $1.38(0.16)$ & - & $3.70(0.38)$ & - & $6.36(0.60)$ & - & - \\
\hline & Acropora pharaonis & $1.97(0.18)$ & $5.86(0.64)$ & $5.29(0.51)$ & $4.63(0.53)$ & $5.36(0.59)$ & $5.56(0.54)$ & $5.36(0.43)$ \\
\hline & Acropora humilis & $3.11(0.34)$ & - & - & $4.45(0.46)$ & $4.07(0.38)$ & $5.01(0.23)$ & $5.00(0.31)$ \\
\hline & Stylophora pistillata & $1.74(0.20)$ & $5.25(0.54)$ & $4.64(0.27)$ & - & $6.00(0.45)$ & $5.58(0.56)$ & $5.74(0.52)$ \\
\hline & Lithophyton arboreum & $4.87(0.32)$ & $2.45(0.21)$ & $5.16(0.50)$ & - & $4.71(0.41)$ & $6.52(0.61)$ & $4.33(0.41)$ \\
\hline & $\begin{array}{l}\text { Sarcophyton } \\
\quad \text { trocheliophorum }\end{array}$ & $3.12(0.35)$ & - & $1.36(0.11)$ & $3.45(0.32)$ & $3.11(0.36)$ & - & - \\
\hline & Sinularia spp. & $7.71(0.64)$ & - & $7.10(0.22)$ & $7.45(0.50)$ & $7.68(0.61)$ & $5.03(0.47)$ & $4.71(0.42)$ \\
\hline
\end{tabular}


Table 2 continued

\begin{tabular}{|c|c|c|c|c|c|c|c|c|}
\hline \multirow[t]{2}{*}{ Metal } & \multirow[t]{2}{*}{ Species } & \multicolumn{7}{|c|}{ Locations } \\
\hline & & I & II & III & IV & $\mathrm{V}$ & VI & VII \\
\hline \multirow[t]{7}{*}{$\mathrm{Fe}$} & Acropora hemprichi & $22.61(1.76)$ & - & $286.21(35.89)$ & - & $37.77(2.55)$ & - & - \\
\hline & Acropora pharaonis & $27.28(1.76)$ & $32.74(2.66)$ & $321.54(32.28)$ & $33.41(1.71)$ & $21.44(1.67)$ & $23.84(1.62)$ & $30.89(1.84)$ \\
\hline & Acropora humilis & $90.01(4.52)$ & - & - & $60.77(3.00)$ & $20.19(1.54)$ & $13.25(1.30)$ & $40.26(1.84)$ \\
\hline & Stylophora pistillata & $16.87(1.17)$ & $61.08(2.18)$ & $297.30(18.48)$ & - & $26.54(1.54)$ & $24.23(1.56)$ & $25.19(1.60)$ \\
\hline & Lithophyton arboreum & $50.43(2.73)$ & $125.908 .91)$ & $55.38(2.59)$ & - & $44.23(1.94)$ & $44.16(2.09)$ & $44.58(1.73)$ \\
\hline & $\begin{array}{l}\text { Sarcophyton } \\
\quad \text { trocheliophorum }\end{array}$ & $36.49(1.60)$ & - & $27.31(1.33)$ & $32.95(1.67)$ & $121.10(6.17)$ & - & - \\
\hline & Sinularia spp. & $44.61(1.72)$ & - & $45.67(2.04)$ & $55.08(2.26)$ & $38.32(1.78)$ & $17.69(1.19)$ & $57.31(2.44)$ \\
\hline
\end{tabular}

Numbers in parentheses indicate the standard deviations (SD)

Hard corals: Acropora hemprichi, Acropora pharaonis, Acropora humilis and Stylophora pistillata

Soft corals: Lithophyton arboreum, Sarcophyton trocheliophorum and Sinularia spp

-: not determined

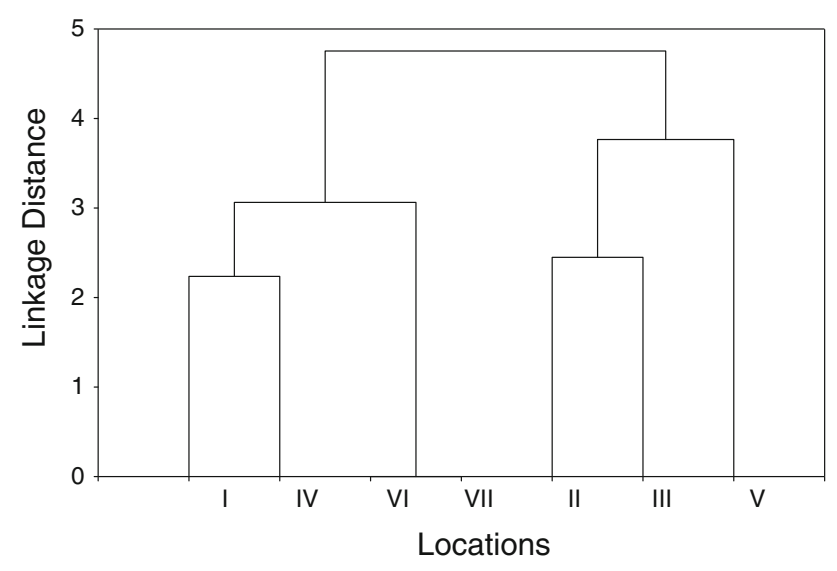

Fig. 2 Cluster analysis dendrogram showing the similarities between the sampling locations in the pollution sources

by adsorption to particles (Clark 1992; Turner 2010). Site II is considered an exposed area characterized by strong water currents and high wave action due to the effect of strong prevailing northerly winds blow in this area. Therefore, it is suggested that these water currents regularly withdraw the copper-bound particles from the coral surface (Fig. 4).

The significant positive correlations (Table 4) between total organic matter content and the concentrations of $\mathrm{Cu}$ in seawater $\left(r^{2}=0.82, t=4.7, P<0.01\right)$ and in sediments $\left(r^{2}=0.66, t=3.13, P<0.05\right)$ indicate the role of organic matter content in complexation and distribution of $\mathrm{Cu}$, and hence increasing its concentration (Al-Abdali et al. 1996; Shriadah 1998). The main causes responsible for increased $\mathrm{Cu}$ concentration at site III include the following: (1) copper and cupric oxide released from the antifouling and anticorrosive paints that coating the structures and marine vessels (Cargo ships and tankers) waiting in the offshore transit area at El-Ain Al-Sukhna. Also the recreational and

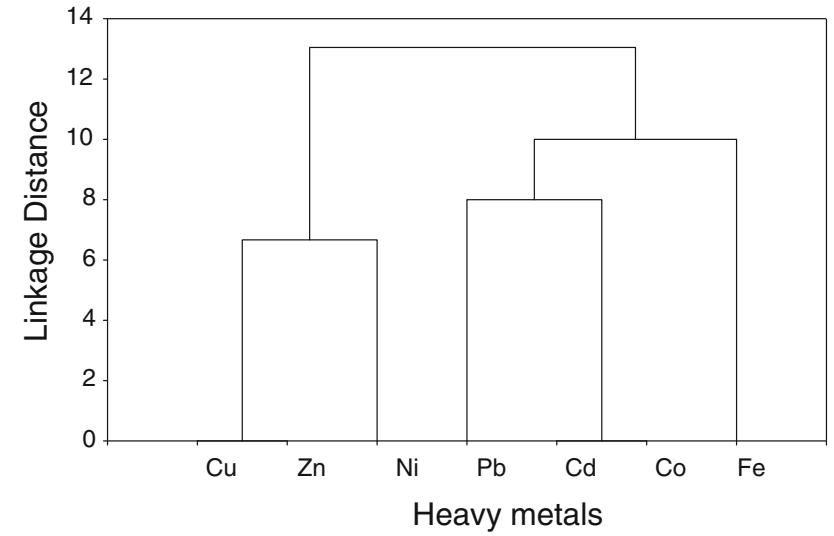

Fig. 3 Tree clustering dendrogram based on the pollution sources showing the similarity among the surveyed metals

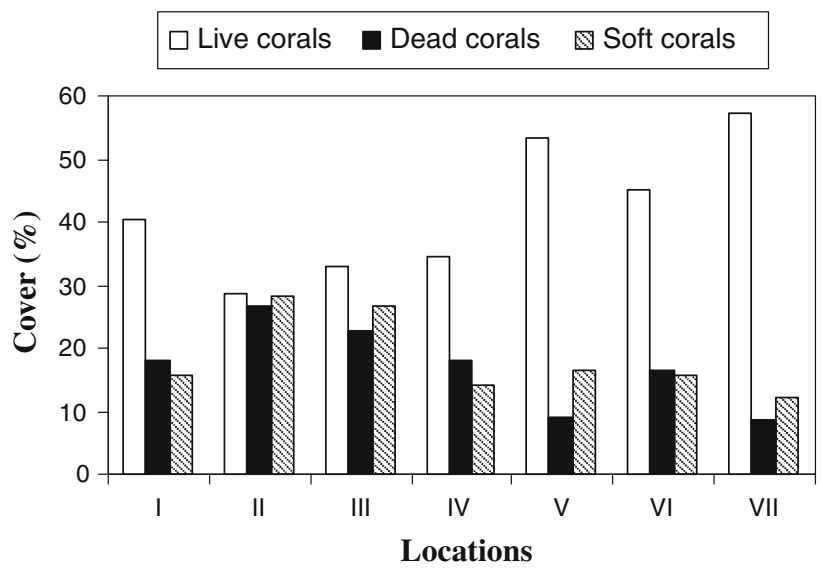

Fig. 4 Percentage covers of live hard, dead and soft corals in the sampling locations

tourist boats waiting in the nearby Marina are coated with $\mathrm{Cu}$-contaminated paints; (2) increased terrestrial runoff of sewage and wastewater from the tourist villages 
and recreational resorts, which are widespread in this area; (3) effluents from new El-Ain Al-Sukhna port and Gulf of Suez Power Plant; (4) higher percentage of organic matter in sediments $(9.95 \%$, Fig. 5) as a result of increased terrestrial runoff, in addition the limited water currents and the slow rate of water exchange in this area tend to enhance the conditions suitable for accumulation of organic matter (Shriadah 1998).

$\mathrm{Cu}$ concentration and bioconcentration factor showed no significant differences among the coral species (ANOVA, $d f=30, F=0.85, P>0.05$, and $d f=30, F=1.24, P>0.05$, respectively). However, Soft corals Sarcophyton trocheliophorum displayed higher mean $\mathrm{Cu}$ concentration, $6.88 \pm 2.26$ (SE) $\mu \mathrm{g} \mathrm{g}^{-1}$ and the greatest bioconcentration factor of $\mathrm{Cu}\left(1.82 \times 10^{3} \mathrm{ppb}\right.$, Table 3$)$ than other corals reported in the current study because it is capable to accommodate a wide range of pollutant concentrations including copper without adverse effects (Haynes and Johnson 2000; Koop et al. 2001) and exhibited higher rate of $\mathrm{Cu}$ accumulation in its tissue. The significant positive correlations (Table 4) obtained between percentage cover of dead corals and $\mathrm{Cu}$ concentrations in seawater $\left(r^{2}=0.67, t=3.15\right.$, $P<0.05)$ and sediments $\left(r^{2}=0.68, t=3.23, P<0.05\right)$ demonstrate the contribution of elevated $\mathrm{Cu}$ levels in enhancing the coral mortality in the area of study (AbdelSalam 1989; Mitchelmore et al. 2007; Sabdono 2009). Consequently, the percentage cover of live corals was significantly decreased with increasing $\mathrm{Cu}$ concentration in seawater $\left(r^{2}=0.67, t=-3.16, P<0.05\right)$ and considerably decreased with increasing $\mathrm{Cu}$ concentration in sediments
Table 3 Mean values of bioconcentration factors $(\times 103 \mathrm{ppb})$ of heavy metals in coral species collected from the area of study

\begin{tabular}{llllllll}
\hline Coral species & \multicolumn{7}{c}{ Metals } \\
\cline { 2 - 8 } & $\mathrm{Cu}$ & $\mathrm{Zn}$ & $\mathrm{Pb}$ & $\mathrm{Cd}$ & $\mathrm{Ni}$ & $\mathrm{Co}$ & $\mathrm{Fe}$ \\
\hline Hard corals & & & & & & & \\
$\quad$ Acropora hemprichi & 1.26 & 3.55 & 31.81 & 7.93 & 2.36 & 13.49 & 5.12 \\
Acropora pharaonis & 1.09 & 1.98 & 45.72 & 11.96 & 2.93 & 15.47 & 3.50 \\
Acropora humilis & 1.22 & 2.74 & 44.64 & 12.56 & 3.17 & 15.22 & 3.65 \\
$\quad$ Stylophora pistillata & 0.97 & 1.51 & 43.37 & 12.28 & 3.20 & 16.01 & 3.60 \\
Soft corals & & & & & & & \\
$\quad$ Lithophyton arboreum & 1.18 & 8.22 & 48.52 & 15.06 & 3.47 & 14.73 & 3.95 \\
$\quad$ Sarcophyton trocheliophorum & 1.82 & 5.64 & 33.42 & 6.23 & 1.47 & 8.63 & 4.39 \\
$\quad$ Sinularia spp. & 1.69 & 5.64 & 54.64 & 16.68 & 9.10 & 20.81 & 3.37 \\
\hline
\end{tabular}

Table 4 Summary of correlations among metals, organic matter, and covers of live and dead corals in all reef sites

\begin{tabular}{|c|c|c|c|c|c|c|c|c|c|c|}
\hline \multirow[t]{2}{*}{ Metal } & \multirow[t]{2}{*}{ Sample } & \multicolumn{3}{|c|}{ Live coral cover } & \multicolumn{3}{|c|}{ Dead coral cover } & \multicolumn{3}{|c|}{ Total organic matter } \\
\hline & & $r$ & $r^{2}$ & $P$ & $r$ & $r^{2}$ & $P$ & $r$ & $r^{2}$ & $P$ \\
\hline \multirow[t]{2}{*}{$\mathrm{Cu}$} & $\mathrm{W}$ & -0.82 & 0.67 & 0.025 & 0.82 & 0.67 & 0.025 & 0.90 & 0.82 & 0.005 \\
\hline & $\mathrm{S}$ & -0.72 & 0.52 & 0.067 & 0.82 & 0.68 & 0.023 & 0.81 & 0.66 & 0.026 \\
\hline \multirow[t]{2}{*}{$\mathrm{Zn}$} & $\mathrm{W}$ & -0.67 & 0.44 & 0.103 & 0.76 & 0.57 & 0.049 & 0.85 & 0.72 & 0.015 \\
\hline & $\mathrm{S}$ & -0.83 & 0.69 & 0.021 & 0.80 & 0.64 & 0.031 & 0.65 & 0.43 & 0.116 \\
\hline \multirow[t]{2}{*}{$\mathrm{Pb}$} & $\mathrm{W}$ & -0.81 & 0.65 & 0.028 & 0.81 & 0.66 & 0.026 & 0.89 & 0.79 & 0.008 \\
\hline & $S$ & -0.92 & 0.85 & 0.003 & 0.89 & 0.80 & 0.007 & 0.81 & 0.65 & 0.029 \\
\hline \multirow[t]{2}{*}{$\mathrm{Cd}$} & $\mathrm{W}$ & -0.52 & 0.27 & 0.236 & 0.48 & 0.23 & 0.278 & 0.96 & 0.92 & 0.001 \\
\hline & $S$ & -0.94 & 0.89 & 0.001 & 0.95 & 0.91 & 0.001 & 0.78 & 0.61 & 0.038 \\
\hline \multirow[t]{2}{*}{$\mathrm{Ni}$} & W & -0.76 & 0.58 & 0.046 & 0.78 & 0.61 & 0.039 & 0.78 & 0.61 & 0.038 \\
\hline & $\mathrm{S}$ & -0.87 & 0.77 & 0.010 & 0.82 & 0.67 & 0.025 & 0.72 & 0.51 & 0.071 \\
\hline \multirow[t]{2}{*}{ Co } & W & -0.79 & 0.61 & 0.038 & 0.80 & 0.64 & 0.031 & 0.96 & 0.92 & 0.001 \\
\hline & $S$ & -0.97 & 0.93 & 0.000 & 0.95 & 0.90 & 0.001 & 0.77 & 0.60 & 0.041 \\
\hline \multirow[t]{2}{*}{$\mathrm{Fe}$} & W & -0.81 & 0.66 & 0.027 & 0.85 & 0.73 & 0.014 & 0.78 & 0.61 & 0.039 \\
\hline & $S$ & -0.36 & 0.13 & 0.429 & 0.28 & 0.08 & 0.547 & 0.22 & 0.05 & 0.635 \\
\hline
\end{tabular}

Correlations are significant at $P<0.05$

$r$ : correlation coefficient, $r^{2}$ : coefficient of determination, $P$ : statistical significance

W: seawater, S: reef sediment 


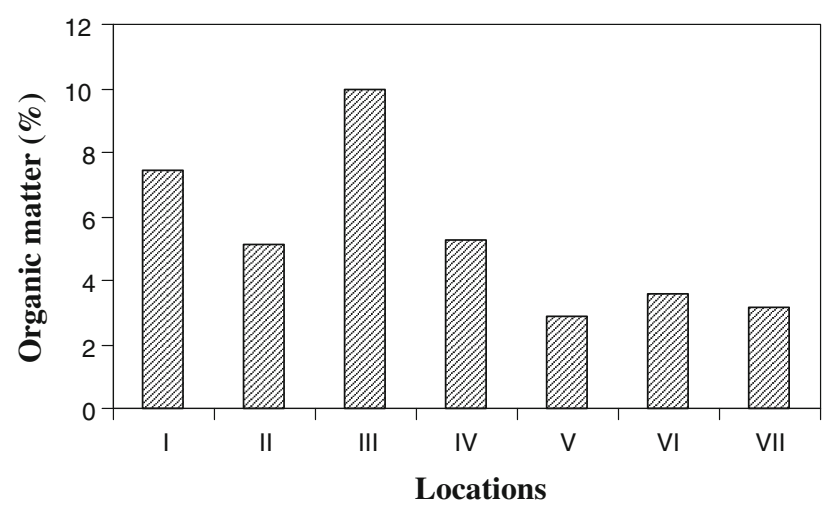

Fig. 5 Percentage of total organic matter in sediment collected from the surveyed reef sites

$\left(r^{2}=0.52, \quad t=-2.33, P>0.05\right)$. Previous studies have shown that the higher concentrations of copper inhibit coral fertilization (Heyward 1988; Reichelt-Brushett and Harrison 1999; Reichelt-Brushett and Michalek-Wagner 2005) reduce the survival and settlement of coral larvae, planulae (Esquivel 1983; Reichelt-Brushett and Harrison 2000). This may be belonging to the major causes responsible for reduced live coral cover with elevated levels of copper.

\section{Zinc}

Zinc concentration recorded throughout the world's open oceans average $5 \mathrm{~g} \mathrm{l}^{-1}$ (Riley and Chester 1989). The Australian Water Quality Guidelines indicate that zinc should not exceed than $50 \mu \mathrm{g} \mathrm{l^{-1 }}$ in marine waters (ANZECC 1992).

Zinc concentration (Table 1) in seawater ranging from $7.18 \pm 0.92 \mu \mathrm{g} \mathrm{l}^{-1}$ at site VII (Dahab) to $15.21 \pm$ $1.19 \mu \mathrm{g} \mathrm{l}^{-1}$ at site III (El-Ain Al-Sukhna), while its concentration in sediments ranging from $3.09 \pm 0.49 \mu \mathrm{g} \mathrm{g}^{-1}$ at site V (Sha'b Rashdan, Gulf of Suez) to $27.8 \pm 3.35 \mu \mathrm{g} \mathrm{g}^{-1}$ at site IV (Al-Tur). Thus, the average $\mathrm{Zn}$ concentration $\left(10.14 \pm 1.15 \mu \mathrm{g} \mathrm{l}^{-1}\right)$ in seawater of the study area exceeds the world's open oceans average $\left(5 \mu \mathrm{g}^{-1}\right)$ and lowers than the threshold concentration of Australian Water Quality Guidelines $\left(50 \mu \mathrm{g}^{-1}\right)$.

Increased sewage and wastewater discharge associated with the growth of coastal cities, tourist villages and recreational resorts; increased terrigenous sediment runoff due to intensive coastal constructions for tourism development and expansion of coastal cities; runoff from commercial, recreational and fishing harbors found in the region; power and desalination plants input; and Zinc contained in antifouling and anticorrosive paints that protect the hulls of marine vessels are the major anthropogenic sources of zinc in the area of study. These factors may be responsible for the relatively elevated levels of $\mathrm{Zn}$ in seawater and sediments (Table 1) at sites I, II, III, IV and VI (Sharm el-Sheikh). Total organic matter content in sediment (Fig. 5) was positively correlated (Table 4) with $\mathrm{Zn}$ concentration in seawater $\left(r^{2}=0.72, \quad t=3.62\right.$, $P<0.05)$ and sediment $\left(r^{2}=0.43, t=1.33, P>0.05\right)$. This relationship reveals that the majority of $\mathrm{Zn}$ in the investigated area is derived from pollutant sources (Shriadah 1998; Turner 2010).

Soft corals Sinularia spp. collected from Site III and Lithophyton arboreum collected from site VI contained the highest concentrations of $\mathrm{Zn}(141.3 \pm 16.87$ and $123.6 \pm 12.43 \mu \mathrm{g} \mathrm{g}^{-1}$, respectively, Table 2 ). The possible explanation is that the environmental factors at sites III and VI can increase $\mathrm{Zn}$ uptake and accumulation in these corals (Waldichuk 1985; Shen et al. 1991), in addition these corals probably able to regulate the high concentration of $\mathrm{Zn}$ in their tissue (Klumpp and Peterson 1979; Peters et al. 1997). The most likely mechanism for incorporation of zinc in corals is a combination of uptake of seawater-soluble metals and incorporation via coral polyp feeding (Howard and Brown 1984).

$\mathrm{Zn}$ concentration was significantly different among the coral species reported in this study (ANOVA, $d f=30$, $F=5.73, P<0.001)$. Lithophyton arboreum displayed the greatest mean concentration $\left(81.51 \pm 9.54 \mu \mathrm{g} \mathrm{g}^{-1}\right)$, while the smallest mean concentration $\left(16.69 \pm 5.44 \mu \mathrm{g} \mathrm{g}^{-1}\right)$ was displayed by the hard coral Stylophora pistillata. This may be attributed to the capability of Lithophyton arboreum to tolerate a wide range of $\mathrm{Zn}$ concentration through performing detoxification mechanisms for accumulated $\mathrm{Zn}$ (Viarengo 1989; Haynes and Johnson 2000) and the greater

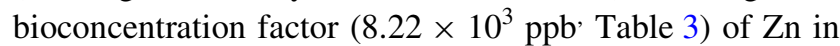
the tissue of this species. The adverse impacts of elevated $\mathrm{Zn}$ concentrations on coral community are indicated by the significant negative relationship $\left(r^{2}=0.69, t=-3.31\right.$, $P<0.05)$ between $\mathrm{Zn}$ concentration in sediments and percentage cover of live hard corals, as well as the significant positive relationships (Table 4) between the percentage cover of dead corals and $\mathrm{Zn}$ concentrations in sweater and sediments $\left(r^{2}=0.57, t=2.59, P<0.05\right.$ and $r^{2}=0.64$, $t=2.97, P<0.05$, respectively).

Lead and cadmium

Lead is among the most pervasive of pollutants has introduced to the marine environment due to human activities. In local coastal regions, lead pollution may also be present in domestic sewage and sewage contaminated with industrial waste (Patterson et al. 1976). Cadmium is highly toxic and originates from anthropogenic activities. De Carlo and Spencer (1995) found that more than $90 \%$ of Cd in marine environment is of anthropogenic origin. Cadmium is a relatively rare element with concentrations ranging from 
$2 \times 10^{-4}$ to $2.9 \mu \mathrm{g} \mathrm{l}^{-1}$ (Sadiq 1992). However, in polluted estuaries or harbors and ports, values up to $50 \mu \mathrm{g} \mathrm{l}^{-1}$ have been recorded (Chester 1990).

Concentrations of $\mathrm{Pb}$ and $\mathrm{Cd}$ in seawater at the investigated sites were generally low and showed no marked differences between sites (Table 2). The range of $\mathrm{Cd}$ concentrations in seawater reported here $\left(0.13-0.43 \mu \mathrm{gl}^{-1}\right)$ is within the normal range of seawater (Sadiq 1992) and less than the critical threshold level $\left(2 \mu \mathrm{g} \mathrm{l}^{-1}\right)$ of the Australian Water Quality Guidelines for marine environment (ANZECC 1992).

The higher concentrations of $\mathrm{Pb}$ and $\mathrm{Cd}$ in sediments reported at sites I, II, III, IV and VI (Tables 1) reflected the influence of anthropogenic stresses. Since these areas are the main recreational centers and coastal cities in the Northern Red Sea, they are undergoing enhanced anthropogenic terrestrial runoff. Increased sewage and wastewaters outfall associated with population growth of the coastal cities, and increasing tourist villages and recreational resorts are among the potential sources of $\mathrm{Pb}$ and $\mathrm{Cd}$ pollution. Sewage levels have been increased in proportion to population growth of coastal cities. Sewage sludge has been reported to contain high lead and cadmium concentrations (Clark 1992; Jayaraju et al. 2009). Also inputs from fishing harbor (site IV), Marina of yachts (site III) and harbors of recreational boats (sites I and VI), and El-Ain Al-Sukhna commercial port (site III) may be substantially contributed to the elevated levels of $\mathrm{Pb}$ and $\mathrm{Cd}$ in sediment at these areas. Gasoline fuel emissions from atmosphere, recreational yachts and fishing boats may increase the $\mathrm{Pb}$ concentration in the area of study (Patterson 1983; Esslemont 2000). Moreover, the lead-made municipal pipelines are considered important source of $\mathrm{Pb}$ in marine environment close to coastal cities. Crude oil is known to contain minor amounts of $\mathrm{Pb}$ (Al-Abdali et al. 1996; Metwally et al. 1997), so it seems likely that the chronic and accidental oil spillage resulted from several sources at sites I and II (during transport, shipping and unloading) acts as an additional cause of elevated $\mathrm{Pb}$ levels in these areas. The higher percentage of total organic matter in sediments (Fig. 5) at sites I, II, III and IV (7.46, $5.13,9.95$ and $5.26 \%$, respectively) could also contribute to increased concentrations of $\mathrm{Pb}$ and $\mathrm{Cd}$ recorded in these sites (Al-Abdali et al. 1996; Shriadah 1998). This contribution is corroborated by the significant proportional relationships between total organic matter content in sediments and concentrations of both $\mathrm{Pb}$ and $\mathrm{Cd}$ in sediments $\left(r^{2}=0.65, t=3.04, P<0.05\right.$ and $r^{2}=0.91, t=7.01$, $P<0.001$, respectively). The range of Cd concentrations in sediments in the present results $(1.97 \pm 0.27-$ $\left.4.3 \pm 0.91 \mu \mathrm{g} \mathrm{g}^{-1}\right)$ is higher than the permissible natural background range $\left(1.2-2.0 \mu \mathrm{g} \mathrm{g}^{-1}\right)$ in the Arabian Gulf region (Al-Abdali et al. 1996).
Incorporation of lead and cadmium into corals can be mainly the result of dissolved metal incorporation, included particulate material absorbed by coral tissue or coral feeding (Brown 1987; Corrège 2006; Al-Rousan et al. 2007). There are some evidences that corals might be able to regulate the concentrations of metal in their tissues (e.g. Peters et al. 1997; Esslemont 2000; Reichelt-Brushett and McOristb 2003; Anu et al. 2007). The regulation of the body metal concentration to an approximately constant level is achieved by balancing excretion to metal uptake (Rainbow et al. 1990). Lead concentration and bioconcentration factor were not significantly different among the coral species of interest (ANOVA, $d f=30, F=1.23$, $P>0.05$ and $d f=30, F=0.53, P>0.05$, respectively). The higher concentrations of lead in corals (Table 2) were reported in soft corals Lithophyton arboreum at sites I and $\mathrm{V}\left(36.00 \pm 2.53 \mu \mathrm{g} \mathrm{g}^{-1}\right.$ and $36.36 \pm 2.97 \mu \mathrm{g} \mathrm{g}^{-1}$, respectively) and Sinularia spp. at sites I and V $(36.00 \pm$ $2.59 \mu \mathrm{g} \mathrm{g}^{-1}$ and $36.01 \pm 2.01 \mu \mathrm{g} \mathrm{g}^{-1}$, respectively). Also cadmium concentration and the bioconcentration factor insignificantly different among coral species (ANOVA, $d f=30, F=1.91, P>0.05$ and $d f=30, F=1.22, q>0.05$, respectively). The highest concentration of cadmium $\left(9.59 \pm 0.69 \mu \mathrm{g} \mathrm{g}^{-1}\right)$ was reported in the tissue of Sinularia spp. at site III (Table 2). These considerable variations may be related to the physicochemical factors of the aquatic medium (Phillips 1980; Esslemont 2000) in the studied sites and the different accumulation strategies of corals (Rainbow et al. 1990; Dallinger and Rainbow 1993; Anu et al. 2007). Increasing salinity of seawater can increase the cadmium uptake (Ramos et al. 2004). Heavy metals and probably other pollutants are expected to be absorbed more rapidly at higher temperatures (Rainbow 1990). It is interesting to note that the higher levels of lead in corals taken from site $\mathrm{V}$ (Table 2) did not reflect low concentrations of $\mathrm{Pb}$ in seawater and sediments at this site (Table 1). It is hypothesized that the environmental parameters at this site may increase the rate of metal uptake and accumulation by corals at the expense of excretion rate (removal of pollutants from tissue), even though the lead concentrations in the environment are very low (Waldichuk 1985; Shen et al. 1991). Furthermore, Sinularia spp. had the greater average concentrations of lead and cadmium $\left(29.07 \pm 3.04 \mu \mathrm{g} \mathrm{g}^{-1}\right.$ and $4.26 \pm 1.12 \mu \mathrm{g} \mathrm{g}^{-1}$, respectively) followed by Lithophyton arboreum $\left(27.31 \pm 4.26 \mu \mathrm{g} \mathrm{g}^{-1}\right.$ and $3.09 \pm 0.46 \mu \mathrm{g}$ $\mathrm{g}^{-1}$, respectively). This can be explained by the rate of lead and cadmium uptake by these corals exceeds the excretion rate, leading to high net accumulation (Phillips 1980). This view can be supported by the higher mean bioconcentration factors of $\mathrm{Pb}$ and $\mathrm{Cd}$ reported in these corals (Table 3). In addition, it is probable that Sinularia spp. and Lithophyton arboreum can store the high concentrations of $\mathrm{Pb}$ and $\mathrm{Cd}$ in detoxified form to avoid the 
possibility of toxic action (Brown and Howard 1985; Peters et al. 1997).

Table 4 reveals that the percentage of dead coral cover was significantly increased with increment concentrations of lead $\left(r^{2}=0.8, \quad t=4.43, \quad P<0.01\right)$ and cadmium $\left(r^{2}=0.91, t=7.01, P<0.001\right)$. Consequently, the percentage of live hard coral cover was significantly $(P<0.01)$ reduced with increasing concentrations of $\mathrm{Pb}$ and $\mathrm{Cd}$ in sediments $\left(r^{2}=0.85, t=-5.38\right.$ and $r^{2}=0.89, t=-6.29$, respectively). The detrimental effects of elevated Cd levels are higher in the earlier live stages of marine organisms than adults (Mance 1987).

\section{Nickel and cobalt}

Nickel is one of the largest trace metal constituents of crude oil (Al-Abdali et al. 199; Metwally et al. 1997) and hence its presence in high concentration in marine environment may indicate direct input from oil pollutants. Cobalt is an essential metal for living organisms in low concentrations but may be toxic in high concentrations (Clark 1992). The concentration of nickel in seawater of the study area ranged from $2.33 \pm 0.26 \mu \mathrm{gl}^{-1}$ at site VII to $5.8 \pm 0.99 \mu \mathrm{gl}^{-1}$ at site III (Table 1). On the other hand, the cobalt concentrations in seawater are very low and showed no marked variation between the surveyed locations.

The higher $\mathrm{Ni}$ concentrations in sediments (Tables 1) recorded at sites II and III $\left(16.36 \pm 1.07{\mu g^{-1}}^{-1}\right.$ and $18 \pm 1.38 \mu \mathrm{gg}^{-1}$, respectively) are nearly coincided with increased petroleum pollution due to chronic and accidental oil spills (Ali 2001) and indicates that the Ni contaminations in these regions are mainly derived from the oil pollutants. The major causes of oil pollution at sites II and III may include the following: 1 . Inevitable oil spills during loading and unloading operations at the platform terminals of SUMED pipeline Company at El-Ain Al-Sukhna; 2. Illegal discharge of oil-contaminated ballast or bilge water from traveling vessels and the tankers waiting in the offshore transit area. 3. Accidental oil spillage due to tankers collisions and pipelines damage 4. Oil-contaminated effluents came from El-Ain Al-Sukhna port, Marina of Yachts and power plant. The relatively elevated Ni levels in sediment reported at site IV $\left(14.23 \pm 1.27 \mu \mathrm{gg}^{-1}\right.$, Table 1$)$ may be as a result of crude oil spillage from nearby oil production fields and oil-contaminated wastewaters of fishing boats and their harbor found in this area. The localized oil pollution associated with enhanced fishing, recreational and tourism activities at site I can explain the considerably raised $\mathrm{Ni}$ concentration in sediment $\left(13.08 \pm 0.53 \mu \mathrm{gg}^{-1}\right)$ registered in this area (Table 1).

Increased terrestrial runoff of terrigenous sediments caused by intensive constructions for recreational purposes and expansion of coastal cities, and the consequent enhanced sewage disposal; wide spreading of tourist units; and discharges from ports and power plants are probably the potential anthropogenic factors accounted for the elevated concentrations of cobalt in sediments at sites I, II, II and IV (Table 1). Higher percentage of total organic matter in sediments (Fig. 5) reported at sites I, II, III and IV (7.46, $5.13,9.95$ and $5.26 \%$, respectively) is also strongly contributed to the higher levels of $\mathrm{Ni}$ and Co reported in these locations (Shriadah 1998). This can be demonstrated by the significant $(P<0.05)$ positive relationships between total organic matter content in sediments and the concentrations of nickel in seawater $\left(r^{2}=0.61, t=2.8\right.$, Table 4$)$ and cobalt in sediments $\left(r^{2}=0.6, t=2.73\right)$. Ni concentration in sediments was also considerably and positively correlated with total organic matter content $\left(r^{2}=0.51, t=2.29, P>0.01\right)$.

Although the variation of $\mathrm{Ni}$ concentration and bioconcentration factor between coral species is not significant, it is certainly obvious (ANOVA, $F=1.08, d f=30, P>0.05$ and $F=1.48, d f=30, P>0.05$, respectively). The highest $\mathrm{Ni}$ concentration contained in soft corals Sinularia spp. collected from site III (186 $\pm 8.54{\mu g g^{-1}}^{-1}$, Table 2) were probably due to the increased $\mathrm{Ni}$ uptake rate associated with elevated dissolved $\mathrm{Ni}$ concentrations $\left(5.8 \pm 0.99 \mu \mathrm{gl}^{-1}\right)$ and high salinity level (annual mean $=41.78 \mathrm{ppt}$ ) reported in this area (Dallinger and Rainbow 1993; Ramos et al. 2004; Ali and Hamed 2006). Also Sinularia spp. exhibited the greatest mean Ni concentration $\left(41.78 \pm 28.86 \mu \mathrm{gg}^{-1}\right)$ in the area of study and the highest bioconcentration factor of Ni $\left(9.1 \times 10^{3} \mathrm{ppb}\right.$, Table 3$)$. This may indicate that this coral has high Ni bioaccumulation capacity and detoxified storage capability of the accumulated nickel (Viarengo 1989).

Similarly, the higher concentrations of cobalt were recorded in Sinularia spp. at sites I, II, IV and VI (Table 2). It is noted that the higher Co concentration in corals collected from site $\mathrm{V}$ (Table 2) did not reflect the relatively low levels of $\mathrm{Co}$ in sediments obtained at this site (Table 1). It is suggested that the physicochemical factors in this location may aid the coral species to increase the Co uptake rate and accumulation (Phillips 1980; Waldichuk 1985). Cobalt concentration was significantly different between the investigated coral species (ANOVA, $F=3.43, d f=30, P<0.05$ ), whereas the highest mean concentration $\left(6.61 \pm 0.56 \mu \mathrm{gg}^{-1}\right)$ in the area of study was reported also in Sinularia spp. This may be related to the capability of this species to take and store Co in detoxified form (Viarengo 1989). The highest bioconcentration factor of Co $\left(20.81 \times 10^{3} \mathrm{ppb}\right.$, Table 3$)$ in tissue of Sinularia spp. demonstrates also the efficiency of this species to accumulate Co in their tissue (Rainbow et al. 1990).

The negative influence of elevated Ni levels on reefbuilding corals is indicated by the significant $(P<0.05)$ 
positive relationships (Table 4 ) between percentage cover of dead corals and concentrations of nickel in seawater $\left(r^{2}=0.61, t=2.77\right)$ and sediments $\left(r^{2}=0.67, t=3.17\right)$. High concentrations of $\mathrm{Ni}$ have been reported to significantly decrease the survival and settlement of coral larvae (Goh 1991). As a result, the percentage cover of live hard corals was significantly lowered with enhanced concentrations of nickel in seawater $\left(r^{2}=0.58, t=-2.64, P<0.05\right)$ and sediments $\left(r^{2}=0.77, t=-4.04, P<0.01\right)$. Similarly, the results revealed that the increased cobalt concentrations in sediments were significantly associated with increased percentage cover of dead corals $\left(r^{2}=0.9, t=6.6, P<0.01\right)$ and declined percentage cover of live hard corals $\left(r^{2}=0.93\right.$, $t=-8.25, P<0.001)$.

\section{Iron}

Higher concentrations of $\mathrm{Fe}$ in sediments and seawater may be revealed a pollution problem in a certain area. Al-Abdali et al. (1996) have shown that the elevated levels of iron in core sediments in the Arabian Gulf ( $>20,000 \mu \mathrm{g} \mathrm{g}^{-1}$ ) may be chronically polluted levels. The range of Fe concentrations in sediments (321.5 $\pm 39.46-$ $2150.6 \pm 155.94{\mu \mathrm{gg}^{-1}}^{-1}$ reported in the present study (Table 1) is much lower than the permissible natural background range in the Arabian Gulf region (10,00020,000 $\mu \mathrm{gg}^{-1}$, Al-Abdali et al. 1996) and the average level in sediments from the Cairns Region of the Great Barrier Reef, Australia (16,000 $\mathrm{gg}^{-1}$, Brady et al. 1994). On the other hand, the range of $\mathrm{Fe}$ concentrations in seawater at the investigated sites $\left(9.1 \pm 0.62-28.35 \pm 3.04 \mu \mathrm{g}^{-1}\right.$, Table 1) is much higher than that $\left(0.06-0.17 \mu \mathrm{g}^{-1}\right)$ reported in most oceans, including Arabian Sea (Measures and Vink 1999; Ferrier-Pages et al. 2001). The higher concentrations of $\mathrm{Fe}$ in seawater recorded at sites II and III (Table 1) were probably resulted from increased terrestrial inputs of terrigenous sediments (Guzman and Jimenez 1992) and chronic oil pollution in these areas (Al-Abdali et al. 1996; Ali 2001). Accidental spills of crude oil and fuel oil contaminated with iron derived from tankers, shipping and ruptured pipeline would act as additional sources of iron in El-Ain Al-Sukhna (site III) and Ras Za'farana (site II). Furthermore, outfalls from El-Ain Al-Sukhna port, Gulf of Suez power plant and marina of yachts may contribute to the high Fe levels in site III. The elevated levels of total organic matter content obtained in sediment at sites II and III (5.13 and 9.95\%, Fig. 5) were also involved in increasing $\mathrm{Fe}$ concentrations in their seawater $\left(r^{2}=0.61, t=2.78, P<0.05\right)$.

The considerably higher Fe concentrations in sediment (Table 1) recorded at sites IV (El-Tur) and VI (Sharm el-Sheikh) can be attributed to the substantial quantities of iron transported with the major winds from the nearby Fe-rich Mountains to the sea. Enhanced terrigenous runoff caused by landfilling concomitant with intensive constructions for tourism development and expansion of coastal cities can be considered additional sources of iron in these locations. Guzman and Jimenez (1992) indicated that the high concentrations of $\mathrm{Al}, \mathrm{Fe}$ and $\mathrm{Mn}$ reported along the Caribbean coast of Central America are indicators of terrigenous sediment contamination in the entire region and probably long-distance transportation. Inputs from Marina Sharm and tourist boats may also increase Fe concentrations in sediments at site VI. In addition, sediments at site IV can be enriched with $\mathrm{Fe}$ upcoming from fishing boats harbor and petroleum production fields situated in the vicinity of El-Tur area.

As the majority of metals in the present study, Fe concentration and bioconcentration factor were not significantly different among the interested coral species (ANOVA, $F=0.36, d f=30, P>0.05$ and $F=0.16$, $d f=30, P>0.05$, respectively), but they showed marked variation between these species (Table 2). The higher Fe concentrations reported in hard corals Acropora hemprichi $\left(286.21 \pm 35.89 \mu \mathrm{gg}^{-1}\right)$, Acropora pharaonis (321.54 \pm $\left.32.28 \mu \mathrm{gg}^{-1}\right)$ and Stylophora pistillata $(297.30 \pm$ $18.48 \mu \mathrm{gg}^{-1}$ ) collected from site III are a direct result to the highest concentration of dissolved Fe registered at this site (Table 1) and probably to the higher salinity level (Ramos et al. 2004; Ali and Hamed 2006). In contrast to the majority of metals reported in the current study, the highest average of $\mathrm{Fe}$ concentration $\left(115.53 \pm 85.45 \mu \mathrm{gg}^{-1}\right)$ was obtained in hard coral Acropora hemprichi. The possible reason is tendency of iron to incorporate into the aragonite of coral skeleton and substitute the dissolved metals species into crystal lattice (e.g. substitution of $\mathrm{Ca}$ ) rather than soft tissue (Scott 1990; David 2003). The highest bioconcentration factor of iron calculated in Acropora hemprichi $\left(5.12 \times 10^{3} \mathrm{ppb}\right.$, Table 3$)$ demonstrates the capacity of this species to accumulate higher concentrations of Fe.

Studies on the effect of iron enrichment on corals are scarce and rely mostly on toxicological experiments or on field studies where iron concentrations were particularly elevated (e.g. Harland and Brown 1989; Brown et al. 1991; Ferrier-Pages et al. 2001). The present results (Table 4) showed that increasing Fe concentration in seawater was accompanied with enhanced percentage cover of dead corals $\left(r^{2}=0.73, t=3.68, P<0.05\right)$ and lowered percentage cover of live hard corals $\left(r^{2}=0.66, t=-3.08, P<0.05\right)$. This can be attributed to that the chronic exposure of corals to higher levels of $\mathrm{Fe}$ may significantly reduce the coral growth rates. Ferrier-Pages et al. (2001) found that growth rates of Stylophora pistillata colonies measured after 3 weeks of $\mathrm{Fe}$ enrichment were $23 \%$ lower than those obtained in control colonies. 


\section{Conclusion}

It is observed that most of the intended heavy metals appear to share the same anthropogenic sources of pollution. In general, the reef sites undergoing increased anthropogenic pressure exhibited elevated levels of heavy metals in seawater, sediments and corals.

The contribution of total organic matter content to heavy metals abundance was indicated by the significant positive correlations found between total organic matter content in sediments and heavy metal concentrations in seawater and sediment.

The results showed that the reef sites (sites II and III) with elevated metal levels had greater abundance of soft corals and reduced abundance of live hard corals compared to less polluted sites. This can be explained by the ability of soft corals to accommodate a wide range of pollutants without adverse effects and colonize the metal-contaminated areas. In addition, hard coral colonies are particularly susceptible to contaminants dissolved in seawater or adsorbed to particles because the layer of tissue covering the coral skeleton is thin (only approx. $100 \mu \mathrm{m}$ ).

With the exception of iron, the soft corals contained higher concentrations of the surveyed heavy metals compared to hard corals. The present study demonstrated also that the elevated metal concentrations were significantly associated with reduced percentage cover of live hard corals and enhanced percentage cover of dead corals.

All the problems associated with heavy metals pollution in coral reef ecosystems will increase substantially in the incoming years, unless the interested Governmental and Non-governmental Organizations adopt sustainable management strategies to protect the coral reef areas and control the pollution sources in cooperation with the ecologists, scientists and other stakeholders.

\section{References}

Abdel-Salam HA (1989) The physiological effects of environmental stress on Atlantic reef corals. Ph. D. thesis, University of Georgia, USA

Al-Abdali F, Massoud, Al-Ghadban AN (1996) Bottom sediments of the Arabian GulfIII. Trace metal contents as indicators of pollution and implications for the effect and fate of the Kuwait oil slick. Environ Pollut 93(3):285-301

Ali AAM (2001) Human impacts on coral reefs along the Egyptian Red Sea coast. Ph.D. thesis, University of Zagazig, Egypt

Ali AAM, Hamed MA (2006) Impact of water quality deterioration on coral reef community structure in the Northern Red Sea, Egypt. Egypt J Aquat Biol Fish 10(2):117-146

Al-Rousan SA, Al-Shloul RN, Al-Horani FA, Abu-Hilal AH (2007) Heavy metal contents in growth bands of Porites corals: record of anthropogenic and human developments from the Jordanian Gulf of Aqaba. Mar Pollut Bull 24(12):1912-1922
Anu G, Kumar NC, Jayalakshmi KV, Nair SM (2007) Monitoring of heavy metal partitioning in reef corals of Lakshadweep Archipelago, Indian Ocean. Environ Monit Assess 128:195-208

APHA, American Public Health Association (1989) Standard methods for the examination of waters and wastewaters, 17th edn. APHA, Washington, pp 203-216

ANZECC, Australian and New Zealand Environment and Conservation Council (1992) Australian water quality guidelines for fresh and marine waters

Bastidas C, Garcia E (1999) Metal content on the reef coral Porites astreoides: an evaluation of river influence and 35 years of chronology. Mar Pollut Bull 38:899-907

Brady BA, Johns RB, Smith JD (1994) Trace metal geochemical association in sediments from the Cairns Region of the Great Barrier Reef, Australia. Mar Pollut Bull 28:230-234

Brown BE (1987) Heavy metals pollution on coral reefs. In: Salvat B (ed) Human impacts on coral reefs: facts and recommendations. Antenne Museum E. P. H. E, French Polynesia, pp 119-134

Brown BE, Holley MC (1982) Metal levels associated with tin dredging and smelting, and their effect upon intertidal reef flats at Ko Phuket, Thailand. Coral Reefs 1:131-137

Brown BE, Howard LS (1985) Assessing the effects of stress on reef corals. Adv Mar Biol 22:1-63

Brown BE, Tudhope AW, Le Tissier MDA, Scoffin TP (1991) A novel mechanism for iron incorporation into coral skeletons. Coral Reefs 10:211-215

Chester R (1990) Marine geochemistry. Allen and Unwin, Australia, p 698

Chester R, Lin FG, Basaham AS (1994) Trace metals solid state speciation changes associated with the down-column fluxes of oceanic particulates. J Geol Soc Lond 151:351-360

Clark RB (1992) Marine pollution. Claredon, Oxford

Corrège $T$ (2006) Monitoring of terrestrial input by massive corals. J Geochem Explor 88:380-383

Dallinger R, Rainbow PS (1993) Ecotoxicology of metals in invertebrates. Lewis Publishers, London, pp 5-23

David CP (2003) Heavy metal concentrations in growth bands of corals: a record of mine tailings input through time (Marinduque Island, Philippines). Mar Pollut Bull 46:187-196

De Carlo EH, Spencer KJ (1995) Records of lead and other heavy metal inputs to sediments of the Ala Wai Canal, O, ahu, Hawaii, vol 49/4. Pacific Science, University of Hawaii Press, pp 471-491

Dodge RE, Gilbert TR (1984) Chronology of lead pollution contained in banded coral skeletons. Mar Biol 82:9-13

Dodge RE, Logan A, Antonius A (1982) Quantitative reef assessment studies in Bermuda: a comparison of methods and preliminary results. Bull Mar Sci 32(3):745-760

Esquivel IF (1983) Short term bioassay on the planula of the reef corals Pocillopora damicornis. In: Jokiel PL, Richmond RH, Rogers RA (eds) Coral reef population biology. Hawaii Institute of Marine Biology technical report 37, pp 465-472

Esslemont G (2000) Heavy metals in seawater, marine sediments and corals from the Townsville section, Great Barrier Reef Marine Park, Queensland. Mar Chem 71(3-4):215-231

Falkowski PG, Dubinsky Z, Muscatine L, McCloskey L (1993) Population control in symbiotic corals: ammonium ions and organic materials maintain the density of zooxanthellae. Bioscience 43(9):606-611

Fallon SJ, White JC, McCulloch MT (2002) Porites corals as recorders of mining and environmental impacts: Misima Island, Papua New Guinea. Geochim Cosmochim Acta 66(1):45-62

Ferrier-Pages C, Schoelzke V, Jaubert J, Muscatine L, HoeghGuldberg O (2001) Response of a scleractinian coral Stylophora pistillata, to iron and nitrate enrichment. J Exp Mar Biol Ecol 259:249-261 
Ferrier-Pagès C, Houlbrèque F, Wyse E, Richard C, Allemand D, Boisson F (2005) Bioaccumulation of zinc in the scleractinian coral Stylophora pistillata. Coral Reefs 24(4):636-645

Goh BL (1991) Mortality and settlement success of Pocillopora damicornis planula larvae during recovery from low levels of nickel. Pac Sci 45:276-286

Guzman HM, Jimenez CE (1992) Contamination of coral reefs by heavy metals along the Caribbean coast of Central America (Costa Rica and Panama). Mar Pollut Bull 24(11):554-561

Hanna RGM, Muir GL (1990) Red Sea corals as biomonitor of trace metal pollution. Environ Monit Assess 14:211-222

Harland AD, Brown BE (1989) Metal tolerance in the scleractinian coral Porites lutea. Mar Pollut Bull 20:353-357

Haynes D, Johnson JE (2000) Oraganochlorine, heavy metals and polyaromatic hydrocarbon pollutant concentrations in the Great Barrier Reef (Australia) environment: a review. Mar Pollut Bull 41(7-12):267-278

Heyward AJ (1988) Inhibitory effects of copper and zinc sulphates on fertilization in corals. Proc 6th Int Coral Reef Symp Aust 2:299303

Howard LS, Brown BE (1984) Heavy metals and reef corals. Oceanogr Mar Biol Ann Rev 22:195-210

Jayaraju N, Sundara Raja Reddy BC, Reddy KR (2009) Heavy metal pollution in reef corals of Tuticorin Coast, Southeast Coast of India. Soil Sediment Contam 18(4):445-454

Kayser H (1976) Waste-water assay with continuous algal cultures: the effects of mercuric acetate on the growth of some marine Dinoflagellates. Mar Biol 36:61-72

Klumpp DW, Peterson PJ (1979) Arsenic and other trace elements in the water and organisms of an estuary in S. W. England. Environ Pollut 19:11-20

Koop K, Booth D, Broadbent A, Brodie J, Bucher D, Capone D, Coll J, Dennison W, Erdmann M, Harrison P, Hoegh-Guldberg O, Hutchings P, Jones GB, Larkum AWD, O'Neil J, Steven A, Tentori E, Ward S, Williamson J, Yellolees D (2001) ENCORE: the effects of nutrient enrichment on coral reefs. Synthesis of results and conclusions. Mar Pollut Bull 42(2):91-120

Leon LM, Warnken J (2008) Copper and sewage inputs from recreational vessels at popular anchor sites in a semi-enclosed Bay (Qld, Australia): estimates of potential annual loads. Mar Pollut Bull 57(6-12):838-845

Machiwa JF (1992) Anthropogenic pollution in the Dar es Salam Harbour area, Tanzania. Mar Pollut Bull 24(11):562-567

Mance G (1987) Pollution threats of heavy metals in aquatic environments. Elsevier, Amsterdam, p 372

Mansour AM, Nawar AH, Madkour HA (2005) Metals concentrations of recent invertebrates along the Red Sea coast of Egypt: a tool for monitoring environmental hazards. Sedimentol Egypt 13:171185

Measures CL, Vink S (1999) Seasonal variations in the distribution of $\mathrm{Fe}$ and $\mathrm{Al}$ in the surface waters of the Arabian Sea. Deep Sea Res 46:1597-1622

Metwally MES, Al-Muzaini S, Jacob PG, Bahloul M, Urushigawa Y, Sato S, Matsmura A (1997) Petroleum hydrocarbons and related heavy metals in the near-shore marine sediments of Kuwait. Environ Int 23(1):115-121

Mitchelmore CL, Verde EA, Weis VM (2007) Uptake and partitioning of copper and cadmium in the coral Pocillopora damicornis. Aquat Toxicol 85:48-56

Oregioni B, Aston SR (1984) The determination of selected trace metals in marine sediment by flameless/flame atomic absorption spectrophotometry. IAEA Monaco Laboratory, International report

Patterson CC (1983) Criticism of "Flow of metals into the global atmosphere". Geochim Cosmochim Acta 47:1163-1168

Patterson CC, Settle D, Glover B (1976) Analysis of lead in polluted coastal seawater. Mar Chem 4:305-319

Peters EC, Gassman NJ, Firman JC, Richmond RH, Power EA (1997) Ecotoxicology of tropical marine ecosystems. Environ Toxicol Chem 16(1):12-40

Phillips DJH (1980) Toxicity and accumulation of cadmium in marine and estuarine biota. In: Nriagu JE (ed) Cadmium in the environment. Part 1. Ecological cycling, New York, pp 426-570

Rainbow PS (1990) Heavy metal levels in marine invertebrates. In: Furness RW, Rainbow PS (eds) Heavy metals in the marine environment. CRC Press, Inc., Florida, pp 67-79

Rainbow PS, Phillips DJH, Depledge MH (1990) The significance of trace metal concentrations in marine invertebrates: a need for laboratory investigation of accumulation strategies. Mar Pollut Bull 21(7):321-324

Ramos AA, Inoue Y, Ohde S (2004) Metal content in Porites corals: anthropogenic input of river runoff into a coral reef from an urbanized area, Okinawa. Mar Pollut Bull 48:281-294

Reichelt-Brushett AJ, Harrison PL (1999) The effects of copper, zinc and cadmium on fertilization success of gametes from scleractinian reef corals. Mar Pollut Bull 38(3):182-187

Reichelt-Brushett AJ, Harrison PL (2000) The effect of copper on the settlement success of larvae from the scleractinian coral Acropora tennis. Mar Pollut Bull 41(7-12):385-391

Reichelt-Brushett AJ, Harrison PL (2005) The effects of selected trace metals on fertilization success of several scleractinian coral species. Coral Reefs 24:524-534

Reichelt-Brushett AJ, McOristb G (2003) Trace metals in the living and nonliving components of scleractinian corals. Mar Pollut Bull 46(12):1573-1582

Reichelt-Brushett AJ, Michalek-Wagner K (2005) Effects of copper on the fertilization success of the soft coral Lobophytum compactum. Aquat Toxicol 74:280-284

Riley JP, Chester R (1989) Introduction to marine chemistry. St. Edmundsbury Press, Great Britain, p 465

Sabdono A (2009) Heavy metal levels and their potential toxic effect on coral Galaxea fascicularis from Java Sea, Indonesia. Res J Environ Sci 3(1):96-102

Sadiq M (1992) Toxic metal chemistry in marine environments. Marcel Dekker, New York, p 390

Schiff K, Diehl D, Valkirs A (2004) Copper emission from antifouling paint on recreational vessels. Mar Pollut Bull 48:371-377

Scott PJB (1990) Chronic pollution recorded in coral skeletons in Hong Kong. J Exp Mar Biol Ecol 139:51-64

Shen GT, Campbell TM, Dunbar RB, Wellington GM, Colgan MW, Glynn PW (1991) Paleochemistry of manganese in corals from the Galapagos Island. Coral Reefs 10:91-100

Shriadah MA (1998) Metal pollution in marine sediments of the United Arab Emirates Creeks along the Arabian Gulf shoreline. Bull Environ Contam Toxicol 60:417-424

Turner A (2010) Marine pollution from antifouling paint particles. Mar Pollut Bull 60(2):159-171

Viarengo A (1989) Heavy metals in marine invertebrates: mechanisms of regulation and toxicity at the cellular level. CRC Crit Rev Aquat Sci 1:295-317

Waldichuk M (1985) Biological availability of metals to marine organisms. Mar Pollut Bull 16:7-11 